\title{
Naked Eye Single Tube Red Cell Osmotic Fragility Test (NESTROFT) - A Brief Review
}

\section{Dr. Pallavi BR*}

Department of Pathology, Mysore Medical College and Research Institute, Mysore, Karnataka, India

DOI: $\underline{10.36348 / \text { sjpm.2020.v05i05.001 }}$

| Received: 21.04.2020 | Accepted: 29.04.2020 | Published: 04.05.2020

*Corresponding author: Pallavi BR

\section{Abstract}

Naked eye single tube red cell osmotic fragility test (NESTROFT) is a simple test to screen for thalassemia has been described for use in developing countries. We studied the articles published before regarding the use of NESTROFT in screening Thalassemia and found out the average sensitivity and negative predictive value was $95.94 \%$ and $95.33 \%$ respectively which indicates NESTROFT is a good screening tool for the beta thalassemia.

Keywords: NESTROFT, Thalassemia screening, Haemoglobinopathies.

Copyright @ 2020: This is an open-access article distributed under the terms of the Creative Commons Attribution license which permits unrestricted use, distribution, and reproduction in any medium for non-commercial use (NonCommercial, or CC-BY-NC) provided the original author and sources are credited.

\section{INTRODUCTION}

Haemoglobinopathies are the commonest hereditary disorders in India and one of the major health problems. Previous studies show that the overall prevalence of beta thalassemia is $3-4 \%$ for every 8000 to 10000 new births. High performance liquid chromatography (HPLC) is expensive and not available everywhere. Naked eye single tube red cell osmotic fragility test (NESTROFT) is a simple test to screen for thalassemia has been described for use in developing countries.

\section{Principle of naked eye single tube osmotic fragility} test

If all the red cells in the tested sample have not undergone lysis in $0.36 \%$ buffered saline indicates a positive NESTROFT. These unlysed red cells resulted in the hazy appearance of the contents of the tube and render the line on the paper indistinct. These red cells also sediment at the bottom of the tube as a button when it is left undisturbed for some time. Thus a positive NESTROFT indicates decreased red cell osmotic fragility and increased resistance to osmotic lysis.

\section{METHOD}

We searched articles of NESTROFT in pubmed central and collected information including number of patients, sensitivity, sensitivity, positive predictive value (PPV) and negative predictive value (NPV). The results were tabulated and compared.

\section{RESULTS}

A total of 17 studies were reviewed which were published in various journals indexed in pubmed. The articles were published between year 1988 to 2012 . Total number of patients including all the studies was 5127 ranging from 42 to 1695 with an average of 333.5 and standard deviation of 443.3. The average sensitivity was $95.94 \%$ ranging from $87 \%$ to $100 \%$ with a standard deviation of $3.5 \%$. The average specificity was $76.17 \%$ ranging from $28.7 \%$ to $100 \%$ with a standard deviation of $20.54 \%$. The average positive predictive value was $67.05 \%$ ranging from $33.6 \%$ to $100 \%$ with a standard deviation of $24.52 \%$. The average negative predictive value was $95.33 \%$ ranging from $82.3 \%$ to $100 \%$ with a standard deviation of $5.89 \%$. The results were tabulated in Table 1.

Tabel-1: Sensitivity, Specificity, PPV and NPV

\begin{tabular}{|c|c|c|c|c|c|}
\hline & $\begin{array}{c}\text { Number of } \\
\text { patients }\end{array}$ & $\begin{array}{c}\text { Sensitivity } \\
(\mathbf{\%})\end{array}$ & $\begin{array}{c}\text { Specificity } \\
(\mathbf{\%})\end{array}$ & $\begin{array}{c}\text { PPV } \\
(\boldsymbol{\%})\end{array}$ & $\begin{array}{c}\text { NPV } \\
(\boldsymbol{\%})\end{array}$ \\
\hline Average & 333.56 & 95.94 & 76.17 & 67.05 & 95.33 \\
\hline Minimum & 42 & 87 & 28.7 & 33.6 & 82.3 \\
\hline Maximum & 1695 & 100 & 100 & 100 & 100 \\
\hline $\begin{array}{c}\text { Standard } \\
\text { deviation }\end{array}$ & 443.3 & 20.54 & 24.52 & 24.52 & 5.89 \\
\hline
\end{tabular}




\section{DISCUSSION}

Kulkarni et al. [1] studied the prevalence of beta thalassemia using NESTROFT as screening test and showed that the cost which was incurred in conducting the NESTROFT was only rupees 1.5 INR per subject, which showed that this was a simple and low cost screening test which can be used for the identification of the carrier status of beta thalassemia in screening large populations, particularly in developing countries at the primary health care centres where laboratory facilities are not available. The average sensitivity of $95.94 \%$ and a NPV of $95.33 \%$ indicate
NESTROFT is a good screening tool for the beta thalassemia.

\section{CONCLUSION}

Hemoglobinopathies are suspected based on hematological parameters like reduced $\mathrm{MCH}$, reduced $\mathrm{MCV}$ and elevated RBC count disproportionate to hemoglobin level. NESTROF test is reliable, cost effective and better screening test for carrier detection. Screening positive cases can be confirmed by HPLC for $\mathrm{HbA} 2$ estimation. It can be used in hemoglobinopathies screening programmes.

Table-2: The results of previous studies

\begin{tabular}{|c|c|c|c|c|c|c|c|c|}
\hline $\begin{array}{l}\text { SI } \\
\text { no }\end{array}$ & Author & Year & Journal & $\begin{array}{l}\text { No of } \\
\text { cases }\end{array}$ & Sensitivity & Specificity & PPV & NPV \\
\hline 1 & Mehta et al. [2] & 1988 & $\begin{array}{l}\text { Indian Journal of } \\
\text { Haematology }\end{array}$ & & $95 \%$ & $82.1 \%$ & $73.1 \%$ & $97 \%$ \\
\hline 2 & Thomas S et al. [3] & 1996 & $\begin{array}{l}\text { Indian Journal of Medical } \\
\text { Research }\end{array}$ & 137 & $98.7 \%$ & $66.6 \%$ & $87 \%$ & $96.5 \%$ \\
\hline 3 & Thool AA et al. [4] & 1998 & $\begin{array}{l}\text { Indian Journal of Pathology } \\
\text { and Microbiology }\end{array}$ & 42 & $95.2 \%$ & $100 \%$ & $100 \%$ & $83.3 \%$ \\
\hline 4 & Bobhate SK et al. [5] & 2002 & $\begin{array}{l}\text { Indian Journal of Pathology } \\
\text { and Microbiology }\end{array}$ & 110 & $97.1 \%$ & $100 \%$ & $100 \%$ & $98 \%$ \\
\hline 5 & Manglani M et al. [6] & 1997 & Indian Pediatrics & 1695 & $94.4 \%$ & $64.2 \%$ & $35.3 \%$ & $97.6 \%$ \\
\hline 6 & Chow J et al. [7] & 2005 & $\begin{array}{l}\text { American Journal of } \\
\text { Hematology }\end{array}$ & 85 & $95 \%$ & $86 \%$ & $94 \%$ & $88 \%$ \\
\hline 7 & Raghavan K et al. [8] & 1991 & Indian Pediatrics & 110 & $95.5 \%$ & $87 \%$ & $70.5 \%$ & $98.3 \%$ \\
\hline 8 & $\begin{array}{l}\text { Sirichotiyakul S et al. } \\
\text { [9] }\end{array}$ & 2004 & $\begin{array}{l}\text { International Journal of } \\
\text { Gynaecology and Obstetrics }\end{array}$ & 446 & 97.6 & 72.9 & 33.6 & 99.5 \\
\hline 9 & $\begin{array}{l}\text { Tongprasert F et al. } \\
{[10]}\end{array}$ & 2010 & $\begin{array}{l}\text { Gynaecologic and Obstetric } \\
\text { Investigation }\end{array}$ & 477 & $100 \%$ & $73 \%$ & $35 \%$ & $100 \%$ \\
\hline 10 & $\begin{array}{l}\text { El-Beshlawy A et al. } \\
\text { [11] }\end{array}$ & 2007 & $\begin{array}{l}\text { Eastern Mediterranean } \\
\text { Health Journal }\end{array}$ & 412 & $87 \%$ & $34.1 \%$ & $47.2 \%$ & $82.3 \%$ \\
\hline 11 & Singh SP et al. [12] & 2008 & Singapore Medical Journal & 124 & 97.7 & $83.3 \%$ & $95.5 \%$ & $90.9 \%$ \\
\hline 12 & Sinha M et al. [13] & 2006 & $\begin{array}{l}\text { Indian Journal of Pathology } \\
\text { and Microbiology }\end{array}$ & 120 & $100 \%$ & $28.7 \%$ & & \\
\hline 13 & Sharma G K et al. [14] & 2013 & $\begin{array}{l}\text { International Journal of } \\
\text { Pediatric Research }\end{array}$ & 121 & $93.22 \%$ & $88.7 \%$ & $88.7 \%$ & $93.22 \%$ \\
\hline 14 & Piplani S et al. [15] & 2013 & $\begin{array}{l}\text { Journal of Clinical and } \\
\text { Diagnostic Research }\end{array}$ & 100 & 100 & $85.47 \%$ & $66 \%$ & 100 \\
\hline 15 & $\begin{array}{l}\text { Maheshwari M et al. } \\
{[16]}\end{array}$ & 1999 & Indian Pediatrics & 1048 & $91 \%$ & $95 \%$ & $55 \%$ & $99 \%$ \\
\hline 16 & Suri V et al. [17] & 2001 & $\begin{array}{l}\text { Indian Journal of } \\
\text { Hematology \& Blood } \\
\text { Transfusion }\end{array}$ & 100 & $97.7 \%$ & $71.7 \%$ & $51.9 \%$ & $99 \%$ \\
\hline 17 & Chakraborthy et al. [18] & 2012 & Iranian Journal of Pathology & 500 & $95 \%$ & $95.8 \%$ & 41.02 & 99.78 \\
\hline
\end{tabular}

\section{REFERENCES}

1. Kulkarni, P., Masthi, N. R., Niveditha, S. R., \& Suvarna, R. (2013). The Prevalence of the Beta Thalassemia Trait among the Pregnant Women who attended the ANC Clinic in a PHC, by using the NESTROF Test in Bangalore, Karnataka. Journal of clinical and diagnostic research: JCDR, 7(7), 1414.

2. Mehta, B. C., Gandhi, S., Mehta, J. B., \& Kamath, P. (1988). Naked eye single tube red cell osmotic fragility test for beta-thalassaemia: population survey. Indian J Haematol, 6, 187-90.

3. Thomas, S., Srivastava, A., Jeyaseelan, L., Dennison, D., \& Chandy, M. (1996). NESTROFT as a screening test for the detection of thalassaemia \& common haemoglobinopathies--an evaluation against a high performance liquid chromatographic method.The Indian journal of medical research, 104, 194-197.

4. Thool, A. A., Walde, M. S., Shrikhande, A. V., \& Talib, V. H. (1998). A simple screening test for the detection of heterozygous beta thalassemia. Indian journal of pathology \& microbiology, 41(4), 423426.

5. Bobhate, S. K., Gaikwad, S. T., \& Bhaledrao, T. (2002). NESTROFF as a screening test for detection of Beta-thalassemia trait. Indian journal of pathology \& microbiology, 45(3), 265-267. 
6. Manglani, M., Lokeshwar, M. R., Vani, V. G., Bhatia, N., \& Mhaskar, V. (1997). 'NESTROFT'-an effective screening test for beta thalassemia trait. Indian pediatrics, 34(8), 702-707.

7. Chow, J., Phelan, L., \& Bain, B. J. (2005). Evaluation of single- tube osmotic fragility as a screening test for thalassemia. American journal of hematology, 79(3), 198-201.

8. Raghavan, K., Lokeshwar, M. R., Birewar, N., Nigam, V., Manglani, M. V., \& Raju, N. B. (1991). Evaluation of naked eye single tube red cell osmotic fragility test in detecting beta-thalassemia trait. Indian pediatrics, 28(5), 469-472.

9. Sirichotiyakul, S., Tantipalakorn, C., Sanguansermsri, T., Wanapirak, C., \& Tongsong, T. (2004). Erythrocyte osmotic fragility test for screening of alpha- thalassemia- 1 and betathalassemia trait in pregnancy. International Journal of Gynecology \& Obstetrics, 86(3), 347350.

10. Tongprasert, F., Sirichotiyakul, S., Piyamongkol, W., \& Tongsong, T. (2010). Sensitivity and specificity of simple erythrocyte osmotic fragility test for screening of alpha-thalassemia-1 and betathalassemia trait in pregnant women. Gynecologic and obstetric investigation, 69(4), 217-220.

11. El Beshlawy, A., Kaddah, N., Moustafa, A., Mouktar, G., \& Youssry, I. (2007). Screening for beta-thalassaemia carriers in Egypt: significance of the osmotic fragility test. EMHJ-Eastern Mediterranean Health Journal, 13 (4), 780-786, 2007.
12. Singh, S. P., \& Gupta, S. C. (2008). Effectiveness of red cell osmotic fragility test with varying degrees of saline concentration in detecting betathalassaemia trait. Singapore medical journal, 49(10), 823.

13. Sinha, M., Panigrahi, I., Shukla, J., Khanna, A., \& Saxena, R. (2006). Spectrum of anemia in pregnant Indian women and importance of antenatal screening. Indian journal of pathology \& microbiology, 49(3), 373-375.

14. Sharma, G.K., Sharma, D., Gulati, R.K.(2016). Use of NESTROFT as a screening test for the carriers of thalassemia major. Int J Pediatr Res. 3(7):502-6.

15. Piplani, S., Manan, R., Lalit, M., Manjari, M., Bhasin, T., \& Bawa, J. (2013). NESTROFT-A Valuable, Cost Effective Screening Test for Beta Thalassemia Trait in North Indian Punjabi Population. Journal of clinical and diagnostic research: JCDR, 7(12), 2784.

16. Maheshwari, M., Arora, S., Kabra, M., \& Menon, P. S. N. (1999). Carrier Screening and Prenatal Diagnosis of b-Thalassemia. Indian Pediatr, 36, 1119-25.

17. Suri, V., Sidhu, P., Kanwal, S., Chopra, B.(2001). Evaluation of Naked Eye Single Tube Red Cell Osmotic Fragility Test NESTROFT as a screening test in detection of beta-thalassemia trait. Int $\mathbf{J}$ Hematology and Blood transfusion, 19: 6-7.

18. Chakrabarti, I., Sinha, S. K., Ghosh, N., \& Goswami, B. K. (2012). Beta-Thalassemia Carrier Detection by NESTROFT: An Answer in Rural Scenario? 